DOI:10.32703/2415-7422-2020-10-2-250-265

UDC 930.85:629.326/.327:069.51 (477)

\title{
Hryhorii Luparenko
}

State Polytechnic Museum at the National Technical University of Ukraine «Ihor Sikorskyi Kyiv Polytechnic Institute»

37, Peremohy Avenue, Kyiv, 03056, Ukraine

e-mail:grega@ukr.net

https://orcid.org/0000-0002-3675-8484

\section{Motorcycle MT10-36 as a landmark of science and technology}

Abstract. Based on the source and comparative analysis of the history of creation, design, and production of the Kyiv Motorcycle Works' motorcycles, the value of the MT10-36 motorcycle as the landmark of science and technology has been determined. It has been shown that the development of a new engine and MT10-36 motorcycle was, first of all, the initiative of the plant's engineers. Ovcharenko M. completed the development of a 650 cubic capacity boxer engine. The design of new units and a vehicle outpaced the technological capabilities of the plant. This led to a delay in introducing new technology into production. The involvement of the Foundry Department of the Kyiv Polytechnic Institute under the leadership of K. Vashchenko made it possible to improve the production technology of the motorcycle engine. The reliability of the engine has increased. The design of the engine of the Kyiv Motorcycle Works was in line with the tendencies of the world motorcycle industry. On the basis of a comparative analysis of the MT10-36 motorcycle design and the Ural motorcycle of the Irbit plant (Russian Federation), the strengths and weaknesses of the vehicle design have been determined. Selected episodes of sales of the Kyiv Motorcycle Plant's motorcycles within the country and abroad have been highlighted. It has been highlighted that the motorcycle was operated in conditions that did not reveal its speed and transport capabilities. The motorcycle's design outpaced the pace of development of transport infrastructure (highways). The basic principles of museification of motor vehicles have been considered. It has been noted that one of the valuable qualities of the landmark of technology is the reflection of the peculiarities of the use of the object and its change after leaving the plants' shop. Some aspects of the principles of technique restoration as a material historical source with the optimal preservation of the landmark and the information reflected in it have been considered. It has been concluded that the MT10-36 motorcycle meets the criteria of the landmark of science and technology in the broad sense of this concept. The motorcycle embodies the original technical solutions of native engineers, reflects the level of development of domestic technology and illustrates the practice of operating motorcycle technology. 
Keywords: Kyiv motorcycle works; engine; Polytechnic museum; exhibit

\section{Introduction.}

Motorcycle is the most popular vehicle in countries with warm climate, where machine-building is developed, but the standard of living is quite low. In Ukraine, the greatest popularity of the motorcycle as a vehicle dates back to the second half of the twentieth century, when the Kyiv and Lviv motor plants were in operation. At that time, the motorcycle from a cheap, simple vehicle turned into a kind of subculture.

Today, along with the fact that the motorcycle remains a means of transport, it has become more of a hobby, a hobby, and an interesting recreation. Illustrating the history of technology, the history of transport development, the activities of outstanding engineers as well as the level of technology development, technical museums also exhibit motor vehicles. The world's leading polytechnic museums such as the Museum of Science (London), the Museum of Science and Industry (Chicago), the National Technical Museum (Prague), the State Polytechnic Museum (Moscow), the German Museum (Munich), and the German Museum of Technology (Berlin) exhibit motorcycle collections. Abroad, some of the best collections of motor vehicles are exhibited in the factory museums that made such products. In such institutions, along with the subject, the history of its creation, use, and modernization is revealed. Enterprises are interested in replenishing such collections and popularizing them. Collections are a means of advertising a new motorcycle.

\section{Analysis on recent researches and publications.}

Considering the motorcycle as a materialized embodiment of technical ideas of a certain time, researchers publish a significant number of works not only of a technical, historical, but also cultural nature. Researchers on the history of motor vehicles reveal the subject not only as a vehicle, the embodiment of technology, but as a unique cultural phenomenon in all interconnections in mass culture: cinema, television, museums, sports, etc. (Krens \& Drutt, 1998; Cole, 2020; Dewey, 2018). Encyclopedic and reference publications combine various aspects of motorcycle design, operation, and museum presentation (Broun, 2003). The number of such works abroad is enormous. Domestic researchers still have to go through such a difficult path to the deep highlighting of motorcycle history. Moreover, both the largest manufacturers of motor vehicles Kyiv and Lviv Motor Plants do not exist today. The main sources of the enterprises' activity are periodicals, including electronic ones, and narratives interviews of engineers, employees of the Kyiv and Lviv Motorcycle Works.

General issues of reflecting the history of the technology development by museum means are well highlighted. A number of issues related to the identification, research and preservation of science and technology landmarks were raised in the works of the employees of the Center for Monument Studies of the National Academy of Sciences and USPHCM (Ukrainian Society for the Preservation of Historical and Cultural Monuments). (Griffen \& Konstantinov, 2008). The issues on research, preservation of 
technique in museums were studied in the works of L. A. Griffen, V. O. Konstantinov, V. V. Kobzar, V. P. Iievliieva, S. V. Romadin., etc. (Griffen et al., 2014). Few works deal with the issues of preservation and presentation of vehicles and technical facilities in the form of monuments and their components. Exhibits of motor vehicles in museums are occasionally mentioned (Gurnak \& Ananchenko, 2012). The equipping of museums with motor vehicles and restoration issues are briefly covered in separate works (Yermolaieva, 2015). However, issues of the history of research, preservation and museumification of motor vehicles do not reach the required depth. Most of the works are of general applied value and are published in the electronic media. A significant part covers the history of a separate subject, its modernization and use. For example: changes in the design of carburetors of motorcycles "Dnipro" (Nikonchuk, 2018).

The interest in the history of the motorcycle has caused the appearance of works in which the formation of the definition of the motorcycle concept and its classification in various fields of use has been investigated. An attempt has been made to study the motorcycle as a landmark of science and technology through the prism of the formation of the domestic term "motorcycle" (Nikonchuk, 2019).

Today, in this direction, practice is significantly ahead of theory. The motorcycle is a popular collector's piece; it is displayed both in private and public museums. Therefore, the issue of improving the selection criteria, the value of a motorcycle as the landmark of science and technology is relevant. The purpose of the research is to determine and highlight the value of the MT10-36 motorcycle as the landmark of the history of technology, the embodiment of technological progress and the materialized contribution of outstanding domestic engineers to technical progress. In the article, based on a source study and a comparative analysis on the history of creation, design and production of the Kyiv Motorcycle Works motorcycles, the value of the MT10-36 motorcycle as a monument of science and technology has been determined. It has been shown that the development of a new engine and motorcycle MT10-36 was, first of all, an initiative of the works' engineers.

\section{Research methods.}

The general methodological basis is the method of historicism, which has been used to study the place of the research object in the system of the national history of technology. According to the formulated goal and available sources, research methods have been selected. A system-structural approach has been applied in studying the relationship between engineering and design developments with their implementation and the expected result of implementation. Critical analysis and comparison of narrative information with other available sources will avoid subjective interpretation of facts. Analysis of the main technical parameters against the background of a critical assessment of the motorcycle design by users, and implemented technical solutions to improve technology will allow evaluating objectively the design of the motorcycle, compare it with analogues, and vehicles close in class. Retrospective analysis as a 
method to reproduce the technology of production and marketing of motor vehicles in the 70-80s of the XXth century has been applied. Experimental methods have been used to test conservation and partial restoration methods that are economical to preserve the historical value of the subject.

\section{Results and discussions.}

The work is based on information published in various reference publications, catalogs, manuals for the operation of motor vehicles, specialized journals for users, for example, the journal "Behind the wheel". As P. Nora noted: "Today the historian is by no means a lonely producer of the past. He shares this role with the judge, the witness, the media and the legislator" (Bondar, 2014, p. 103). This necessitated the widespread involvement of narrative sources, interviews, news resources, primarily electronic media - due to their efficiency and quick response to users' requests. The request for information on domestic motorcycle production prompted the emergence of short but informative interviews with engineers, technologists, heads of institutions that were involved in the production, sales and service of Mototechnics (Auto consulting, 2020). These interviews bring in unique facts that need verification. The subject (researcher, engineer) is "endowed with living feelings, emotions, passions, and is considered as an individual" (Pylypchuk \& Strelko, 2018, p. 354). This is due to the use of certain biographical research methods.

An indispensable source of information was a visual inspection, experience of operating and studying motor vehicles in the expositions of domestic museums and during the conservation of museum exhibits. One of the world's first motorcycles was created in 1885 by Gottlieb Daimler and Wilhelm Maybach as "a horse-riding machine with a kerosene engine". Structurally, the motorcycle resembled a bicycle of a "safe" design with two wheels of the same size, an engine between them, a drive to the rear wheel, and a driver's seat above the engine with two smaller supporting wheels (Firsov, 2012, p. 29). Motorcycles have been widespread due to the affordable price compared to the car and the simple design, high power density. These vehicles were especially delighted in Europe and the USA in the first half of the 20th century. This is the time of real passion for vehicles with internal combustion engines, their conquest of high speeds and continents. The first domestic serial motorcycle was manufactured in Kharkiv in 1931 by the Kharkiv car assembly works. 10 motorcycles designed by P. Labura were made. Later, after testing the cars and making changes to the design, the plant had produced motorcycles called HMZ-1M in small series until 1933. Kharkiv residents went further and developed several models with different types of frames, different engines, with a chain final drive and cardan. However, the top leadership of the USSR decided not to produce motorcycles in Kharkiv. Since 1941, the "Serp and Molot" plant was to begin production of heavy M-72 motorcycles - a Soviet copy of the BMW R71. But this was prevented by the war (Pevzner, 1994; Auto24, 2019). 
In September 1945, the Kyiv Motorcycle Works was created on the basis of the Armored Repair Plant No. 8 in Kyiv. The first specialized product was the 2.3 - strong motorcycle K-1B "Kievlyanin", a copy of the German motorcycle "Wanderer-1Sp", which was manufactured on equipment exported from Germany. Since 1949, the production of the M-72 motorcycle has begun on the basis of documents transported from the town Gorkyi, machine tools and motorcycles' spare parts. In 1956 a new, completely own model K-750 was launched into serial production (Sukhovskii, 2004). Since 1968, the works has begun mass production of the K-650 motorcycle, after the introduction of a new principle of motorcycle indexing; it was named MT-8 "Dnepr" (MT-heavy motorcycle). Since then, almost all KMZ motorcycles have been called "Dnepr" with the model number indication, despite the official indexes of the manufacturer. The motorcycle had a new top-valve engine of its own design. Since 1972, a new model MT-10 with a new gearbox with a reverse gear has been launched. The production of the MT10-36 model has begun since 1977 (Sukhovskii, 2004). The number 36 indicates the engine power. According to other data the works has begun the production of the $36 \mathrm{hp}$ engine since January 1976 (Ovcharenko \& Shypota, 1976). This model summarized all the experience of development and operation of Kyiv production motorcycles. It embodied interesting solutions tested by the operation of sports and escort heavy motorcycles. MT10-36 (Fig. 1) in contrast to the previous model (MT-9) had 12-volt electrical equipment, a more powerful generator - which improved lighting, performance indicators of various systems and light alarms.

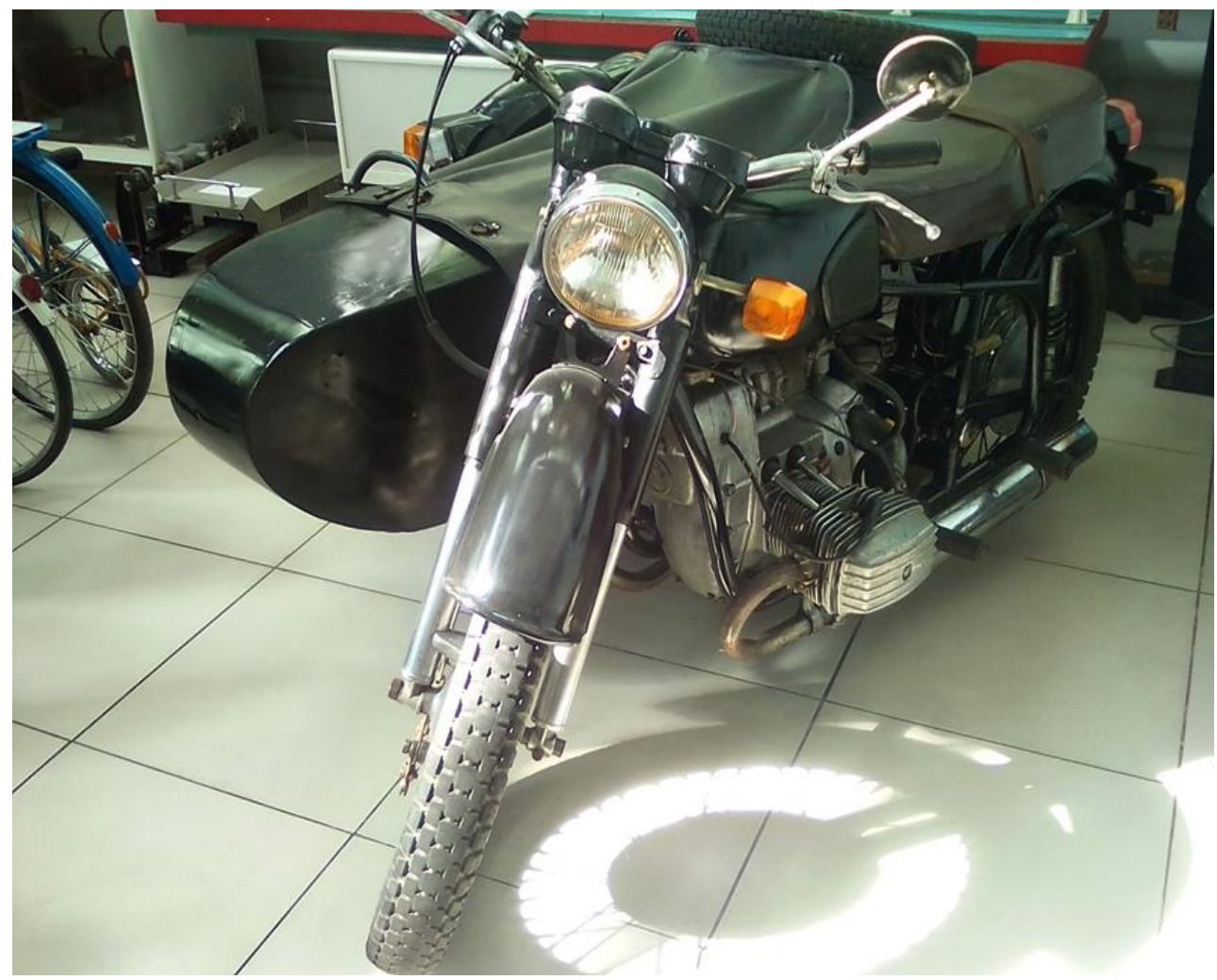

Figure 1. MT10-36 motorcycle in the exposition of the Polytechnic Museum (Kyiv) (Author's photo). 
A double drivers and passenger's seat was installed, which improved driving conditions at low temperatures. The side trailer remained without brake. The motorcycle could be operated without a side trailer, the front fork shock absorber covers had a hole for installing the right turn indicator (Avtoeksport, 1979, pp. 2-7). The main directions of modernization were caused by the adoption of new state standards to improve safety and reduce noise. These works were reduced to the improvement of the brake system - the introduction of a two-cam system with two active brake pads. The front brake had the ability to adjust as the pads wear out, first by connecting the union and then repositioning the cam. "Such a device has been used for the first time on domestic heavy motorcycles" (Yarmak, 1977). Metal clamps were introduced on the fuel flow line under the tank. The parking brake lock has been installed on the front brake lever. A steering wheel lock to prevent motorcycle theft has been installed. The front end of the wing has been flared. The muffler has been modernized, its fastening with cap nuts has been introduced (Yarmak, 1977). But the biggest differences between the MT10-36 models were in the design of the increased power engine. These improvements were not regulated by the new safety standard. They were a natural continuation of the long-term work of KMZ engineers to improve the characteristics of the engine of their own development. The engine of its own design was put into mass production in 1968, unlike its predecessor - it was not a lower-valve, but an overhead valve. The scheme of upper-valve engines has been known since the 30s. In particular, BMW had been producing motorcycles with both upper and lower opposed valves since 1929. The motorcycle with the lower-valve opposite engine became widely used in armies. Unlike the upper valve motorcycles, it had smaller dimensions in width, fewer parts, higher reliability and simplicity. In the early 50s, a heavy motorcycle was no longer perceived as a purely military vehicle. The troops were increasingly using high-powered vehicles, armored personnel carriers, which better performed the role of motorization means of the army.

This upper-valve scheme allowed optimizing working processes in the cylinder, to increase power and to improve efficiency. Focusing on the civil market the motorcycle works begins mass production of motorcycles with upper-valve engines. Confirmation of this is the fact that for a long time MV-750 with a lower valve engine was made for the military after the mass production organization of the upper valve engine. Thus the trend is typical for the evolution of opposing motorcycles abroad. The trend has not spared our country either.

The new engine has absorbed the experience of production and operation of both motorcycle engines, as well as tested design solutions and technological developments of the automotive industry. The engine was developed in 1966 (according to other sources in 1960 (Zapisnaya knizhka mototsiklista, 2015) as KMZ-801 had an aluminum alloy crankcase (silumin), bimetallic cast-iron liners with aluminum alloy fins. All cast crankshafts was with split crank heads and sleeve bearings (from the car Moskvych 407). Lubrication system was with a fashionable at the time cleaning centrifuge, although a few years earlier a project with a paper filter was created 
(Ocherki po istorii KMZ, 2019). Nowadays, the system of cleaning with a paper filter is more common; at that time it could not be implemented due to the inability of the industry to produce filter elements in the required quantity.

Gradually, this engine displaces the previous model of the low-valve engine from production, which was in production until the early 80s. Improving the engine, increasing its power and, in general, the characteristics of the motorcycle are reflected in the name-MT10-36. The lack of detailed information on the MT10 motorcycle led to the fact that there is sometimes information that the MT10 engine also had a power of 36 hp. (Nikonchuk, 2018, p. 42). However, this is not true. The engine was equipped with a new K-301D carburetor of higher throughput (larger diffuser and throughput of the main discharge jet). The engine had an increased intake valve head from 38 to 40 $\mathrm{mm}$. The profile of the camshaft cams was changed to optimize operation at high speeds. The shape of the depression at the bottom of the piston was changed (Ovcharenko, \& Shypota, 1976). The gas distribution shaft in this motor allowed filling quickly the combustion chambers with a working mixture. The compression ratio of the engine was increased due to the use of a hemispherical piston and a short sleeve (Shypota, 1986). The maximum number of revolutions of the crankshaft was $5900 \mathrm{rpm}$. The torque was $4.8 \mathrm{~kg}-\mathrm{cm}$. The engine reached its maximum power at almost maximum speed. This means that it was adapted primarily to improved paved roads. This mode of operation required the improvement of the lubrication system. In general, the engine, which development began in 1960 under the leadership of M. Ovcharenko, did not exhaust the possibilities of modernization and was gradually improved (Zapisnaya knizhka mototsiklista, 2015).

The Kyiv Polytechnic Institute also made its contribution to the improvement of KMZ motorcycles. For a long time, the most short-lived part of a motorcycle engine was the assembled crankshaft, the service life of which was 20-25 thousand $\mathrm{km}$ of run. Together with the department of foundry of KPI in 1963-1966, the design of the crankshaft was worked out. It was cast into shell molds of high-strength cast iron. The test showed that after 40 thousand $\mathrm{km}$. mileage wear on the crankshaft journals is minimal. The department of foundry of KPI under the leadership of K. Vaschenko developed the technology of casting and processing of prefabricated steel piston cylinders with aluminum radiators (Bashtova, 2020, p. 34) and improved the technology of the engine's block casting. The mass of the engine block decreased and the casting accuracy increased. Therefore the time consumption for post-casting processing decreased (Luparenko, 2020, pp. 169-170). The MT10-36 motorcycle was one of the most powerful in the USSR. At the same time, the Irbit plant began production of motorcycles with a $36 \mathrm{hp}$ engine. However, "Dnipro" had a significant advantage in performance. Users noted the softness and precision of gear shifting of the "Dnipro" gearbox, the impossibility of jumping over the gear, sometimes it happened on Irbit motorcycles. And most importantly is the reverse gear, which was switched on with a separate lever. On the "Ural" motorcycle, a gearbox with reverse gear appeared in 1986. For a motorcycle, this seems superfluous. But you have to take 
into account that a motorcycle of this class is a small truck. Therefore, it is not easy to roll over, manually deploy a 300-kilogram car, and even more so a loaded one. Therefore, having a reverse gear is a necessity and does not seem like a bonus. In addition, the "Dnipro" gearbox had a semi-automatic clutch. When you press the gearshift lever, a special protrusion of the gearshift lever through the pull rod pressed on the lower part of the gear box release lever (Avtoeksport, 1979, p. 44). In addition, in this way, the possibility of turning on the speed with the gear box not disengaged was eliminated, and therefore the cause of frequent transmission breakdowns was eliminated. Additionally, in the event of a break in the gear box cable, it was possible to start driving and a full, trouble-free ride without engaging the lever and gear box cable, usually with minimal driver training. All of this has improved the reliability and performance of the gear box. The extraordinary popularity of the motorcycle was due to its availability and free sale. The price of MT10-36 was 1640 rubles (1984). For comparison, ZAZ 968 cost 4500 rubles (1979) while the power of the ZAZ engine was $40 \mathrm{hp}$ at its own weight of $840 \mathrm{~kg}$ and the "Dniro" $36 \mathrm{hp}$ at $325 \mathrm{~kg}$. The motorcycle was a cheaper, more affordable vehicle. It was bought mainly by villagers (Shypota, 1986). This means that it was used mainly in the conditions of unpaved, crushed stone, gravel, and less often paved and asphalt roads. The operation of a vehicle in the countryside implied its more frequent use for transporting not passengers but goods for the needs of peasant farms. Moreover, users often retrofitted the motorcycle with a cargo platform above the spare wheel. For use with a motorcycle, a single-axle trailer was made. It was attached to a hitch mounted between the motorcycle and the tube (to the frame of the side trailer). Thus, the volume and weight of the transported cargo was increased. The Kyiv Motorcycle Works manufactured motorcycles with a cargo side trailer in a small series. In the late 80 s of the twentieth century some enterprises, for example the Odessa car assembly plant, mastered the production of a limited series of trailers for heavy motorcycles. This confirms the specific perception of a heavy motorcycle as a truck. That is, the MT10-36 motorcycle was used as a cargo vehicle: simple, cheap, reliable, powerful. MT10-36 speed parameters could be realized only with improved road surfaces. Operation of the motorcycle did not reveal its best characteristics - maximum power at high speeds. "The basic parameters of its engine are not quite satisfactory for motorcyclists who live in rural areas. When driving on unpaved, stone, rubble roads, they almost never use their maximum power (36 hp)" (Shypota, 1986). The operation of the motorcycle on roads with poor quality surfaces meant that the motorcycle did not develop its maximum power, overextending the fuel. Moreover, at medium crankshaft speeds, the power of the MT10-36 engine was less than the MT10 with a $32 \mathrm{hp}$ engine. Users noticed this feature. The Kyiv Motorcycle Works management was forced to respond to the wishes of users. The next model MT11 had a lower power of $32 \mathrm{hp}$. but with the ability to develop high power already at medium engine speeds (Shypota, 1986). Therefore, the MT10-36 remained the most powerful serial domestic motorcycle, embodying the latest technical ideas and 
domestic technologies of the 60-70 of the XX-th century. However, for objective reasons, it could not use the design and operational advantages.

For a long time, the "Dnipro" motorcycle was used for filming various feature films. Most often it was used as a BMW R71 by Wehrmacht motorcyclists in almost all domestic films of the early - mid-80s of the XXth century. The uninitiated viewer did not pay attention to the clear rectangular outlines of the "Dnipro" cylinder heads, which markedly distinguished it from the BMW during the Second World War. As a common vehicle in the early 80s the MT10-36 motorcycle was also recorded in Western European cinema. It was the MT10-36 motorcycle that starred in the films "Ace" and "Let's argue?" on which Adriano Celentano rode. By the way, it was filmed the actor's motorcycle (Fig. 2) (As, 2017). Motorcycles of the Kyiv plant were exported abroad, in particular in Germany, the Netherlands, Switzerland, Cuba, Argentina and a number of other countries. The motorcycles of the Kyiv Motorcycle Works were sold in 50 countries of the world (Auto consulting, 2020).

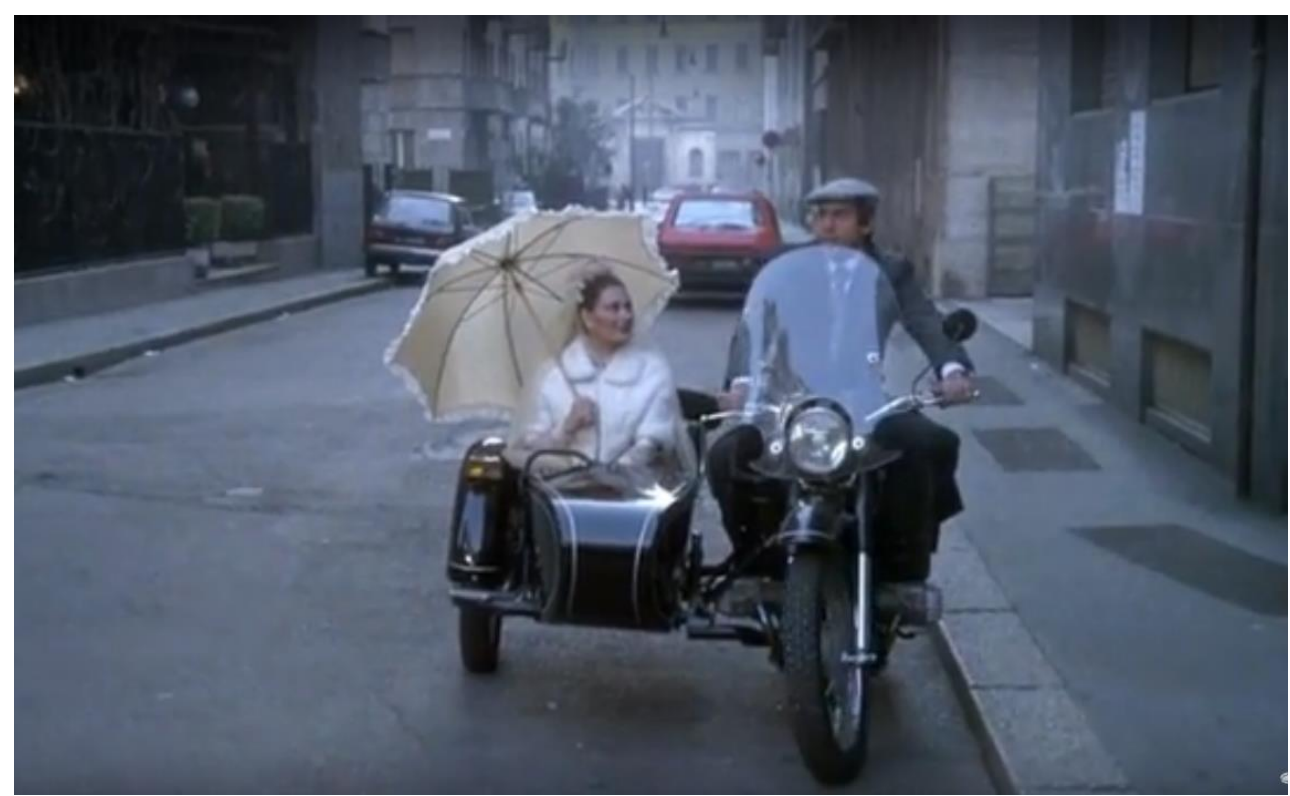

Figure 2. Frame from the feature film "Ace" in 1981 (As, 2017).

Advertising Soviet cars and motor vehicles, the Italian campaign Martorelli made a run across the Sahara Desert. 4 UAZ vehicles and one MT-9 motorcycle participated in the race. (Fig. 3.), (As, 2017).

In 2017, a group of craftsmen who were not indifferent to the fate of KMW decided to assemble new motorcycles. The Vintage series was released - until now it has been the last series of the Dnipro motorcycles. This series is only indirectly related to KMW since the motorcycles were assembled from new factory-made components that were found. The series was made in a two-tone color. Additionally, they installed something that was not in the works models: additional lighting, LED illumination of a license plate, a lubrication indicator, a voltmeter and a taillight. Installed: winch, protective arches, audio system with Mp3-player and alarm (Auto consulting, 2020). 
The winch, safety arches, audio system with Mp3 player, and alarm were installed in it (Auto consulting, 2020). A certain similarity between the MT10-36 and BMW motorcycles contributed to the insignificant sales of relatively cheap domestic motorcycles abroad as "vintage" vehicles that were restored and repaired abroad (Auto consulting, 2019). But in this regard, the K-750 motorcycle is much more popular, which is more similar to the legendary BMW R71.

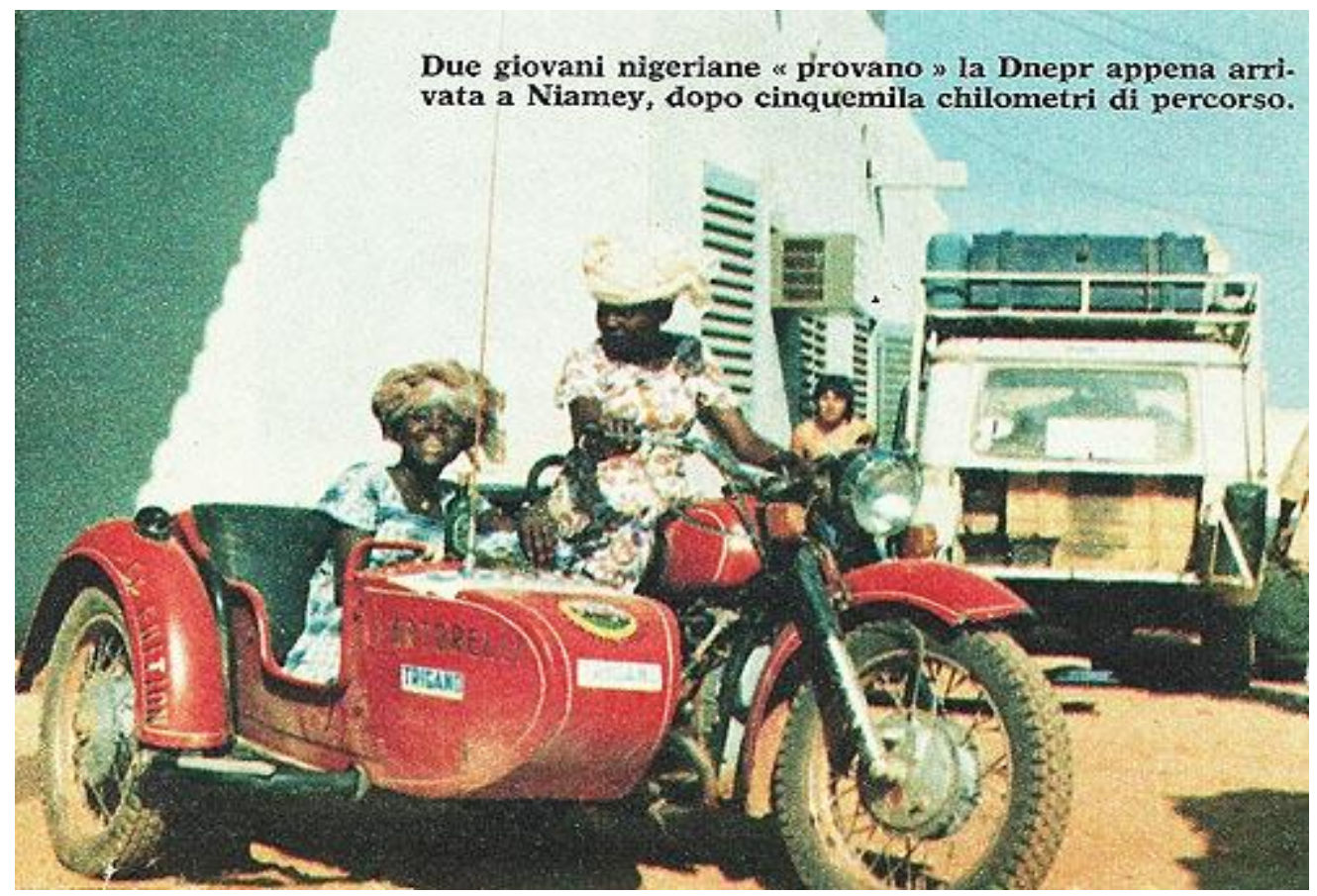

Figure 3. MT9 motorcycle in Africa (from the advertising article "Martorelli") (As, 2017).

Today the MT10-36 motorcycle can be seen less and less on city streets. A significant number of them are not used for technical and economic reasons. However, people's interest in such means, their reflection of important events and phenomena in the history of technology, causes the need for their preservation and exhibiting in museums. Motorcycles of the Kyiv Works are exhibited by: the Museum of Retromotors in Lviv, the private collection of Oleksandr Frolov (Kam'ianske), the Museum of Technology of Buslaev (Zaporizhzhia), the Museum of Motorcycles (Uman). Herewith the motorcycles K-1, M-72, K-650, MV-650, MT-11, MT-14, MT16 are exhibited. But it was the MT10-36 motorcycle that was not recorded. However, a significant number of private collections in Ukraine are not covered in the mass media, so we can cautiously say that the MT10-36 motorcycle in the State Polytechnic Museum is still the only one in the museum collection in Ukraine.

MT10-36 from the exposition of the State Polytechnic Museum was made in January 1979. On January 26, the millionth motorcycle rolled off the assembly line of KMW. The motorcycle is in working order; its completeness according to the model is more than $90 \%$ (Fig. 1). Very rare units and parts, such as a side trailer wheel cover, a 
parking brake, metal air ducts, and a double seat lock have survived. It should be noted that up to now the domestic practice of restoration of vehicles involved, in fact, a major overhaul. The vehicles are disassembled to units and parts, defective, worn parts are replaced, cleaned of dirt and old paint, polished, covered with anti-corrosion coatings, modern paints and varnishes. That is why the items look completely new, "shine" unusually. Such works inevitably lead to a wrong perception of the subject and generally distort the truth of the perception of historical facts and phenomena. For example, the painted parts of the KMZ were not varnished, and in some periods the soil was not used. The reason for this attitude is the methodologically incorrect perception of the historical information content of technology. This principle of restoration has long been abandoned in domestic historical museums. In some cases, a motorcycle is restored with similar original paints and varnishes, which are ordered from manufacturers who specializing in this (Yermolaieva, 2015). Abroad, in general, the maximum safety with minimal restoration intervention or repair is appreciated (Gantriis, 2013, pp. 60-65).

After leaving the shop gate the vehicle certainly changes in the process of operation and use. These changes take place not only in the direction of wear of parts and items. The owner is already involved in the improvement of the vehicle. He equips it additionally, modernizes, and improves in accordance with his own needs. Often the vehicle is mounted with units, which are made in other companies and are not included in the basic package. Unfortunately, until recently, in modern domestic restoration practice, due attention to such changes has not been paid. Today, such additions are differently evaluated, researched and stored as evidence of the degree of conformity of the model to the user's needs and the embodiment of technical thought, ideas of the time.

Conservation involves the maximum preservation of the authenticity of the transferred item. The motorcycle transferred to the museum has some cases of modernization of components and parts. Taking into account the principle of the return of restoration works, these changes were preserved whenever possible. Motorcycle parts were cleaned from excrescences and corrosion and painted. The paint coating of assemblies and parts, which was in good condition, has been preserved. However, for the safety of visitors, hazardous sharp parts of welding flux and metal droplets have been removed. Thus, the motorcycle has retained evidence of production history, operation and further development.

\section{Conclusions.}

Thus, MT10-36 "Dnipro" illustrates a separate branch of the domestic transport engineering, is the creation of domestic engineers, an extremely popular vehicle at the time, embodies domestic technologies in transport engineering. The ideas introduced into the design were somewhat ahead of the readiness of the operation infrastructure; they were given as signs on the further development of the implemented ideas. The involvement of the department headed by the famous scientist K. Vaschenko to 
improve the motorcycle adds value to the exhibit. Strengthening the information content of the exhibit is possible if the history of the object creation is illustrated with additional information from documentary sources, which determines the direction of further scientific research. The high degree of safety of the motorcycle, provided that it is economically restored, will certainly contribute to the effective presentation of the vehicle in the exhibition and will interest the visitors of the Polytechnic Museum.

\section{References}

As, O. (2017). Kak sozdavalsya imidzh sovetskoy tehniki za rubezhem [How the image of Soviet technology was created abroad]. Retrieved from http://motostrangers.ru/motorcycles/kak-sozdavalsya-imidzh-sovetskoj-tehnikiza-rubezhom/ [in Russian].

Auto24. (2019). Chomu inozemtsi vyvoziat z Ukrainy mototsikly MT "Dnipro" [Why do foreigners export Dnipro motorcycles from Ukraine]. Retrieved from https://auto.24tv.ua/chomu_inozemtsi_vyvoziat_z_ukrainy_mototsykly_mt_dnip ro 12177 [in Ukrainian].

Auto consulting. (2019). Kakim byil pervyii ukrainskii mototsikl [What was the first Ukrainian motorcycle]. Retrieved from http://autoconsulting.ua/article.php?sid=45115 [in Russian].

Auto consulting. (2020). Kievskomu motozavodu ispolnilos 75 let [Kiev Motorcycle Plant is 75 years old]. Retrieved from https://www.autoconsulting.com.ua/article.php?sid=47355 [in Russian].

Avtoeksport. (1979). Mototsikl «Dnepr» MT10-36. Instruktsiia po ekspluatatsii [Motorcycle "Dnepr" VT10-36. Operating instructions]. Moskva: Avtoeksport [in Russian].

Bashtova, L. S. (2020). Profesor K. I. Vashchenko - orhanizator matalurhiinoho fakultetu KPI (do 120 richchia vid dnia narodzhennia) [Professor K. Vashchenko is the organizer of the metallurgical faculty of KPI (to the 120th anniversary of his birth)]. Materialy 19-yi Vseukrainskoi naukovoi konferentsii «Aktualni pytannia istorii nauky i tekhniky» - Materials1 of the 9th All-Ukrainian science conferences "Actual nutrition of the history science and technology". Kyiv: KPI [in Ukrainian].

Bondar, V. (2014). Suchasna ukraiinska istoriografiia: pidsumky i vyklyky [Contemporary Ukrainian historiography: results and challenges]. Istoriografichni doslidzhennia $v$ Ukraini - Historiographical research in Ukraine, 25, 95-113. Retrieved from http://dspace.nbuv.gov.ua/bitstream/handle/123456789/95364/06-

Bondar.pdf? sequence $=1$ [in Ukrainian].

Braun, R. (2003). Mototsikly: entsiklopediya [Motorcycles: encyclopedia]. Moskva: OOO Izdatelstvo «Rosme-Press» [in Russian]. 
Cole, L. (2020). Classic Car Museum Guide: Motor Cars, Motorcycles and Machinery. Pen and Sword Transport.

Dewey, Ch. (2018). Motorcycle Collector Talks "American Icon: The Art of the Motorcycle". Retrieved from https://www.grmag.com/entertainment/motorcyclecollector-talks-american-icon-the-art-of-the-motorcycle/ .

Firsov, A.V. (2012). Boris Lutskiy - sozdatel pervogo v mire motorizovannogo velosipeda klassicheskoy komponovki $\mathrm{s}$ dvigatelem vnutrennego sgoraniya [Boris Loutzky - Creator of the world's first motorized bicycle classic layout with a combustion engine]. Doslidzhennya z istorii tehniky - Research in History of Technology, 4, 42-49. Retrieved from http://journal.museum.kpi.ua/archive/2012-vol-16/RHT-issue-16-title-03Firsov.pdf [in Russian].

Gantriis, P. (2013). The Art of BMW: 90 Years of Motorcycle Excellence. Motorbooks International.

Griffen, L. O., \& Konstantinov, V. O. (2008). Ukrainskiy tehnichniy muzey [Ukrainian Technical Museum]. Nizhyn: Aspekt-Poligraf [in Ukrainian].

Griffen, L. O., (Eds.). (2014). Aktualizatsiya naukovo-tehnichnoi spadschini $v$ pamiatkoohoronnii ta muzeynii diyalnosti [Actualization of scientific and technical heritage in monument protection and museum activities]. Kyiv [in Ukrainian].

Gurnak, V. M., \& Ananchenko, O. E. (2012). Vysvitlennya vazhlyvih podiy poviazanih $\mathrm{z}$ avtomobilnym transportom [Coverage of important events related to road transport]. Visnyk Natsionalnogo transportnogo universytetu - Herald of the National Transport University, 26(2), 512-525. Retrieved from http://publications.ntu.edu.ua/visnyk/26_2_2013/512-525.pdf [in Ukrainian].

Krens, T., \& Drutt, M. (1998). The Art of the Motorcycle (New York: The Guggenheim Museum, 1998); see also Michael Kimmelman, "Machines As Art, And Art As Machine". New York Times.

Luparenko, H. V. (2020). Mototsykl MT10-36 "Dnipro" yak vtilennia vnesku spivrobitnykiv KPI v motobuduvannia [The MT10-36 "Dnipro" motorcycle is used to bring sportsmen KPI into the motorcycle]. Materialy 19-yi Vseukrainskoi naukovoi konferentsii «Aktualni pytannia istorii nauky i tekhniky» - Materialsof the 19th All-Ukrainian science conferences "Actual nutrition of the history science and technology". Kyiv: KPI [in Ukrainian]. https://doi.org/10.5281/zenodo.4266967

Nikonchuk, D. O. (2018). Modernizatsiia bloku prigotuvannia goriuchoii sumishi v mototsiklah seriii «Dnipro» [Modernization of the unit of mixture preparation in motorcycles of the Dnipro series]. Pytannia istorii nauky i tehniky -Issues on the history of science and technology, 3, 39-43. Retrieved from http://dspace.nbuv.gov.ua/bitstream/handle/123456789/163556/08-

Nikonchuk.pdf?sequence $=1$ [in Ukrainian]. 
Nikonchuk, D. O. (2019). Mototsykl yak pamiatka istorii tekhniky: konstruktsiia, rozvytok, vyznachennia [Motorcycle as a landmark to the history of technology, construction, development, definition]. Pytannia istorii nauky i tehniky - Issues on the history of science and technology, 1, 70-76 [in Ukrainian]. https://doi.org/10.5281/zenodo.3974472

Ocherki po istorii KMZ (versiya konstruktora KMZ) 1963-1972. (2019). [Essays on the history of KMZ (designer version) 1963-1972]. Retrieved from https://oppozit.ru/article104747.html [in Russian].

Ovcharenko, N., \& Shypota, F. (1976). Modernizirovannyii dvigatel Dnepra [Upgraded Dnipro engine]. Za rulem - Behind the wheel, 10, 22-23 [in Russian]. Pevzner, E. (1994). Mototsikly iz Harkova [Motorcycles from Kharkov]. Retrieved from http://www.kolyaska.pl/charkow.html [in Russian].

Pylypchuk, O., \& Strelko, O. (2018). Istorychnyi analiz vplyvu diialnosti S. Iu. Vitte na rozvytok zaliznychnoho transportu u Rosiiskii imperii [Historical analysis of the influence of $\mathrm{S}$. Yu. Witte on the development of rail transport in the Russian Empire]. Iсторія науки і техніки - History of science and technology, 8(2(13), 353-367 [in Ukrainian]. https://doi.org/10.32703/2415-7422-2018-8-2(13)-353$\underline{367}$

Shypota, F. (1986). Dvigatel MT-10-32 [MT-10-36 engine]. Za rulem - Behind the wheel, 1, 30 [in Russian].

Sukhovskii, S. (2004). Kievskomu mototsikletnomu zavodu - 60 let: Istoki «Dnepra» [Kiev Motorcycle Plant is 60 years old: The origins of the Dnieper]. Retrieved from https://www.autocentre.ua/news/retro/kievskomu-mototsikletnomuzavodu-60-let-istoki-dnepra-291156.html [in Russian].

Yarmak, Ya. (1977). Dnepr MT-10-36. Modernizirovannyiy mototsikl Dnepr [Dnepr MT-10-36. Upgraded motorcycle Dnepr]. Za rulem - Behind the wheel, 3, 12-13 [in Russian].

Yermolaieva, I. V. (2015). Formy ta metody zbyrannya i komplektuvannya kolektsii $v$ memorialnomu kompleksi «Natsionalnii muzei istorii Velikoi Vitchyznianoii viyny 1941-1945 rokiv» [Forms and methods of collecting and completing collections in the memorial complex "National Museum of the History of the Great Patriotic War of 1941-1945"]. Retrieved from http://www.museum.dp.ua/article_2015_30.html [in Ukrainian].

Zapisnaya knizhka mototsiklista. (2015). Istoriia Kievskogo mototsikletnogo Zavoda [History of the Kiev motorcycle plant]. Retrieved from http://itmir.org/moto/?p=387 [in Russian].

\section{Григорій Лупаренко}

Державний політехнічний музей при НТУУ «КПІ ім. Ігоря Сікорського», Україна

\section{Мотоцикл МТ10-36 як пам'ятка науки і техніки}


Анотація. В статті на основі джерелознавчого та порівняльного аналізу історї створення, конструкції та виробництва мотоциклів Київського мотоциклетного заводу визначено изіність мотоцикла МТ10-36 як пам'ятки науки і техніки. Показано, щзо розробка нового двигуна та мотоиикла МТ10-36 була, в першу чергу, ініціативою інженерів заводу. Завершив розробку опозитного двигуна об'смом 650 см $^{3}$ Овчаренко М. Конструкція нових вузлів та транспортного засобу випереджала технологічні можливості виробництва заводу. Це спричинило затримання у впроваджені нової техніки у виробництво. Залучення кафедри ливарного виробництва Київського політехнічного інституту під керівництввом К. Ващзенко, дозволило покращчити технологію виробництвва двигуна мотоичикла. Підвищилась надійність роботи двигуна. Конструкиія двигуна Київського мотоциклетного заводу відповідала тенденизї світового мотобудування. На основі порівняльного аналізу конструкції мотоичкла МТ10-36 та мотоцикла «Урал» Ірбітського заводу (Російська Федерація) визначаються слабкі та сильні сторони конструкиії транспортного засобу. Висвітлено окремі епізоди збуту мотоичклів Київського мотозаводу в середині країни та за кордоном. Висвітлено, щуо мотоцикл експлуатувався в умовах, щзо не розкривали його швидкісних та транспортних можливостей. Конструкиія мотоцикла випереджала темпи розвитку транспортної інфраструктури (шосейних доріг). Розглянуто основні принцуипи музеєфікації мототехніки. Відзначено, щуо однією із цінних якостей пам'яток техніки $\epsilon$ відображення особливостей використання предмету та його зміни після виходу з цуеху заводу. Розглянуто окремі аспекти принциипів реставрації техніки як матеріального історичного джерела із оптимальним збереженням пам'ятки та відображеної в ній інформації. Зроблено висновок про відповідність моточикла МТ10-36 критеріям пам'ятки науки $i$ техніки в иирокому розумінні изього поняття. Мотоцикл втілюе оригінальні технічні рішення вітчизняних інженерів, відображає рівень розвитку вітчизняної техніки та ілюструє практику експлуатаиії мотоичклетної техніки.

Ключові слова: Киїський мотоциклетний завод; двигун; політехнічний музей; експонат

\section{Григорий Лупаренко}

Государственный политехнический музей при НТУУ «КПИ им. Игоря Сикорского», Украина

\section{Мотоцикл МТ10-36 как памятник науки и техники}

Аннотация. В статье на основе источниковедческого и сравнительного анализа истории создания, конструкции и производства мотоциклов Киевского мотоичклетного завода определена цеенность мотоичикла МТ10-36 как памятники науки и техники. Показано, что разработка нового двигателя $u$ 
мотоичикла МТ10-36 была, в первую очередь, иницчиативой инженеров завода. Завершил разработку оппозитного двигателя объемом $650 \mathrm{~cm}^{3}$ Овчаренко М. Конструкиия новых узлов и транспортного средства опережала технологические возможности производства завода. Это привело к задержанию во внедрении новой техники в производство. Привлечение кафедры литейного производства Киевского политехнического института под руководством К. Ващенко, позволило улучшить технологию производства двигателя мотоцикла. Повысилась надежность работы двигателя. Конструкция двигателя Киевского мотоииклетного завода отвечала тенденции мирового мотостроения. На основе сравнительного анализа конструкции мотоичкла МТ10-36 и мотоичикла «Урал» Ирбитского завода (Российкая Федерациия) определяются слабые и сильные стороньл конструкции транспортного средства. Освещуены отдельные эпизоды сбыта моточиклов Киевского мотозавода внутри страны и за рубежом. Показано, что мотоцикл эксплуатировался в условиях, которые не раскрывали его скоростных $u$ транспортных возможностей. Конструкция моточзикла опережала темпь развития транспортной инфраструктуры (иоссейных дорог). Рассмотрены основные принциипы музеефикации мототехники. Отмечено, что одной из ценнных качеств памятников техники является отражение особенностей использования предмета и его изменения после выхода из иеха завода. Рассмотрень отдельные аспекты принцуипов реставрации техники как материального исторического источника с оптимальньм сохранением памятника и отраженной в ней информацчии. Сделан вывод о соответствии мотоичикла МТ10-36 критериям памятники науки и техники в иироком смысле этого понятия. Мотоцикл воплощуает оригинальные технические решения отечественных инженеров, отражает уровень развития отечественной техники и иллюстрирует практику эксплуатации мотоциклетной техники.

Ключевые слова: Киевский мотоциклетный завод; двигатель; политехнический музей; экспонат

Received 21.06.2020

Received in revised form 22.09.2020

Accepted 06.10.2020 